\title{
UPAYA MENINGKATKAN KEMAMPUAN SISWA DALAM MEMAHAMI KONDISI WILAYAH DAN POSISI STRATEGIS INDONESIA SEBAGAI POROS MARITIM DUNIA MELALUI METODE STAD
}

\author{
Dede Mulyadi \\ SMA Negeri 1 Kawali, Jl. Poronggol Raya No. 9, Kawali, Ciamis, Indonesia \\ Email:ddm.amies@gmail.com
}

\begin{abstract}
The aim of the research was to identify the effectiveness of STAD method to improve abilility in understanding territorial condition and strategical position of Indonesia as the central of world maritime of students class XI IPS 4 SMA Negeri 1 Kawali in academic year 2019/2020; and to describe learning process by means of STAD method to improve abilility in understanding territorial condition and strategical position of Indonesia as the central of world maritime at class XI IPS 4 SMA Negeri 1 Kawali in academic year 2019/2020. The targeted change variable was the students' abilility in understanding territorial condition and strategical position of Indonesia as the central of world maritime, meanwhile the action variable of the research was STAD method. This classroom action research was held in two cycles; each cycle contains four steps, they are planning, action, observing, and reflecting. The subject of the research was 33 students of class XI IPS 4 SMA Negeri 1 Kawali in academic year 2019/2020. The data were collected through observation and test, at which they were analyzed by using critical and interactive method containing three main steps; they were reducing the data, describing the data, and making conclusion. The research proved that STAD method was effective to improve abilility in understanding territorial condition and strategical position of Indonesia as the central of world maritime of students class XI IPS 4 SMA Negeri 1 Kawali in academic year 2019/2020. From the collected data of pra cycle, first cycle, and second cycle, it inficated that the existency of improvement in material mastery level was about $15 \%$. Meanwhile, the improvement of learning graduation was about $78,8 \%$.
\end{abstract}

Keywords: STAD Method

\begin{abstract}
ABSTRAK
Tujuan penelitian ini adalah untuk mengidentifikasi efektivitas metode STAD dalam mengoptimalkan kemampuan memahami kondisi wilayah dan posisi strategis Indonesia sebagai poros maritim dunia bagi siswa kelas XI IPS 4 SMA Negeri 1 Kawali tahun pelajaran 2019/2020; dan mendeskripsikan proses pembelajaran memahami kondisi wilayah dan posisi strategis Indonesia sebagai poros maritim dunia dengan menggunakan metode STAD di kelas XI IPS 4 SMA Negeri 1 Kawali tahun pelajaran 2019/2020. Variabel yang menjadi sasaran perubahan dalam penelitian ini adalah kemampuan memahami kondisi wilayah dan posisi strategis Indonesia sebagai poros maritim dunia siswa kelas XI IPS 4 SMA Negeri 1 Kawali tahun pelajaran 2019/2020, sedangkan variabel tindakan yang digunakan dalam penelitian ini adalah metode kooperatif tipe STAD. Penelitian tindakan kelas ini berlangsung dalam dua siklus. Tiap siklus terdiri dari 4 tahapan yaitu perencanaan, pelaksanaan tindakan, observasi dan refleksi. Subyek penelitian adalah siswa kelas XI IPS 4 SMA Negeri 1 Kawali tahun pelajaran 2019/2020 yang berjumlah 33 orang. Teknik pengumpulan data yang digunakan adalah observasi dan tes. Teknik analisis data yang digunakan dalam penelitian ini adalah teknik analisis kritis dan interaktif. Adapun teknik analisis interaktif, adalah teknik analisis yang prosesnya dilakukan dengan tiga langkah, yaitu reduksi data, penyajian data, dan penarikan kesimpulan atau verifikasi. Penelitian ini membuktikan bahwa metode kooperatif tipe STAD efektif untuk meningkatkan kemampuan memahami kondisi wilayah dan posisi strategis Indonesia sebagai poros maritim dunia siswa kelas XI IPS 4 SMA Negeri 1 Kawali tahun pelajaran 2019/2020. Dari data yang dikumpulkan dari tindakan pra siklus, siklus 1 , dan siklus 2 , peneliti melihat adanya peningkatan pada tingkat penguasaan materi sebesar $15 \%$. Sedangkan peningkatan ketuntasan belajar sebesar $78,8 \%$.
\end{abstract}

Kata Kunci: Metode STAD

Cara sitasi: Mulyadi, D. (2020). Upaya Meningkatkan Kemampuan Siswa dalam Memahami Kondisi Wilayah dan Posisi Strategis Indonesia sebagai Poros Maritim Dunia melalui Metode STAD. J-KIP (Jurnal Keguruan dan IImu Pendidikan) , 1 (2), 11-18. 


\section{PENDAHULUAN}

Moral salah satu kompetensi geografi di kelas XI IPS 4 SMA Negeri 1 Kawali tahun pelajaran 2019/2020, siswa dituntut untuk mampu memahami kondisi wilayah dan posisi strategis Indonesia sebagai poros maritim dunia. Dalam silabus geografi di kelas XI IPS SMA Negeri 1 Kawali terkait materi ini, terdapat beberapa indikator pencapaian kompetensi diantaranya: 1) Memahami letak, luas, dan batas wilayah Indonesia, dan 2) Mengetahui karakteristik wilayah daratan dan perairan Indonesia.

Poros maritim merupakan gagasan yang dilontarkan oleh presiden terpilih Joko Widodo saat kampanye pemilihan presiden beberapa waktu lalu. Perlu dikembalikan lagi kesadaran bangsa Indonesia tentang jati dirinya sebagai bangsa maritim. Posisi Indonesia sebagai negara kepulauan yang strategi diapit dua benua Asia dan Australia, serta dua samudra, Hindia dan Pasifik sangat stategis untuk menjadikan Indonesia sebagai poros maritim dunia.

Namun, data awal penelitian terhadap kinerja guru dan perilaku siswa kelas XI IPS 4 memperlihatkan kondisi awal proses pembelajaran memahami kondisi wilayah dan posisi strategis Indonesia sebagai poros maritim dunia. Guru masih menggunakan metode konvensional. Kinerja guru ini berdampak pada perilaku siswa kelas XI IPS 4 dalam mengikuti pelajaran. Dari 33 orang siswa yang ada di kelas XI IPS 4 , hanya $\leq 25 \%$ saja yang mampu dalam kegiatan-kegiatan akademik, memiliki motivasi yang besar terhadap pembelajaran, efektif dalam menggunakan waktu pembelajaran, memiliki sikap percaya diri, mampu bekerjasama, dan memiliki sikap kebaikan budi, kepekaan, dan toleransi. Sisanya $(51 \%$ - $75 \%)$ tidak termotivasi, malu-malu, tidak mampu bekerjasama sehingga mereka tidak memperlihatkan sikap yang mungkin saja mereka miliki seperti kebaikan budi, kepekaan, dan toleransi.

Kinerja guru dan perilaku siswa kelas XI IPS 4 seperti yang telah dijelaskan berdampak negatif terhadap pemerolehan nilai siswa pada tes awal. Fakta-fakta tersebut mengakibatkan semua siswa kelas XI IPS 4 tidak dapat mencapai tujuan pembelajaran. Dari hasil tes awal dapat diketahui bahwa hampir semua siswa kelas XI IPS 4 mendapat nilai di bawah KKM (di bawah 75). Hanya sebagian kecil saja yang mendapat nilai di atas atau sama dengan 75 (7 orang). Ini berarti bahwa dari tes didapatkan hasil yang tidak memuaskan, tampak bahwa ketuntasan belajar hanya mencapai $21,2 \%$ saja dengan rata-rata kelas hanya sebesar 67,7 .

Berdasarkan data yang terkumpul di awal penelitian, peneliti menyimpulkan bahwa kemampuan siswa kelas XI IPS 4 SMA Negeri 1 Kawali dalam memahami kondisi wilayah dan posisi strategis Indonesia sebagai poros maritim dunia sangat rendah sekali. Proses pembelajaran dengan metode konvensional tidak efektif membuat siswa mencapai tujuan pembelajaran.

Untuk dapat mamahami materi ini, siswa memerlukan kegiatan yang dapat menguatkan kemampuan mereka dalam kegiatan-kegiatan akademik, memberi motivasi yang besar terhadap pembelajaran, meningkatkan efektivitas waktu pembelajaran dalam menyelesaikan tugas, menumbuhkan sikap percaya diri, memupuk kemampuan anak dalam bekerjasama, dan melatih sikap kebaikan budi, kepekaan, dan toleransi.

Peneliti dan dua orang observer memutuskan untuk menggunakan metode STAD dalam pembelajaran memahami kondisi wilayah dan posisi strategis Indonesia sebagai poros maritim dunia di kelas XI IPS 4 SMA Negeri 1 Kawali. Metode ini menyediakan langkah-langkah pembelajaran dengan menyampaikan tujuan pembelajaran, memotivasi siswa, menyajikan informasi, mengorganisasikan siswa ke dalam kelompok-kelompok belajar, membimbing kelompok belajar, melaksanakan evaluasi, dan memberikan penghargaan. Langkah-langkah tersebut dipadukan dengan pendekatan scientific yang merupakan ciri khas kurikulum 2013. Dengan menggunakan metode STAD ini diharapkan siswa kelas XI IPS 4 SMA Negeri 1 Kawali dapat meningkatkan kemampuannya dalam memahami kondisi wilayah dan posisi strategis Indonesia sebagai poros maritim dunia.

Berdasarkan latar belakang yang telah diuraikan, maka rumusan masalah pada penelitian ini yaitu: 1) Apakah metode STAD dapat meningkatkan kemampuan memahami kondisi wilayah dan posisi strategis Indonesia sebagai poros maritim dunia siswa kelas XI IPS 4 SMA Negeri 1 Kawali 
tahun pelajaran 2019/2020?; 2) Bagaimana proses pembelajaran menggunakan metode STAD untuk meningkatkan kemampuan memahami kondisi wilayah dan posisi strategis Indonesia sebagai poros maritim dunia siswa kelas XI IPS 4 SMA Negeri 1 Kawali tahun pelajaran 2019/2020?

\section{METODE PENELITIAN}

Penelitian tindakan kelas ini dilaksanakan di SMA Negeri 1 Kawali yang berada di Jalan Poronggol Raya Nomor 09 Kecamatan Kawali Kabupaten Ciamis, kode pos 46253. Penelitian tindakan kelas ini berisi kegiatan persiapan, tindakan pra siklus, siklus 1 dan siklus 2, serta penyusunan laporan penelitian yang semuanya itu dilaksanakan mulai tanggal 29 Juli 2019 sampai 16 Desember 2019.

Subyek dari penelitian tindakan ini adalah siswa kelas XI IPS 4 SMA Negeri 1 Kawali tahun pelajaran 2019/2020 dengan jumlah murid sebanyak 33 orang. Penelitian ini merupakan proses pengkajian sistem berdaur sebagaimana kerangka berpikir yang dikembangkan oleh Supardi (dalam Arikunto, 2008). Prosedur penelitian mencakup tahapan-tahapan sebagai berikut: (1) perencanaan (planning), (b) tindakan (action), (c) observasi dan evaluasi proses dan hasil tindakan (observation and evaluation), dan (d) melakukan refleksi (reflecting) dan seterusnya sampai perbaikan atau peningkatan yang diharapkan tercapai.

Dalam penelitian tindakan kelas ini, peneliti mengumpulkan data dengan menggunakan teknik observasi dan tes.

\section{a. Observasi}

Observasi yang peneliti lakukan adalah peneliti berperan secara pasif. Observasi ini dilakukan oleh dua orang observer (teman sejawat) yaitu Bapak Drs. Totong Budiarto dan Ibu Yeni Sulastri, S.Pd. untuk mengamati kinerja peneliti dan perilaku siswa kelas XI IPS 4 selama proses pembelajaran berlangsung. Lembar observasi untuk mendapatkan data tentang kinerja peneliti dan perilaku siswa disusun menurut teori yang ada tentang pelaksanaan metode STAD di kelas.

b. Tes

Tes pada penelitian ini dilaksanakan pada setiap akhir siklus yang berupa tes tulis pilihan ganda. Pemberian tes ini dimaksudkan untuk mengukur seberapa jauh peningkatan kemampuan siswa kelas XI IPS 4 SMA Negeri 1 Kawali dalam memahami kondisi wilayah dan posisi strategis Indonesia sebagai poros maritim dunia sebelum dan sesudah pemberian tindakan dengan metode STAD.

Teknik analisis data yang digunakan dalam penelitian ini adalah teknik analisis kritis dan interaktif. Teknik analisis kritis bertujuan untuk mengungkap kekurangan dan kelebihan perilaku siswa kelas XI IPS 4 dan kinerja peneliti dalam proses belajar mengajar di kelas selama penelitian berlangsung. Adapun teknik analisis interaktif, menurut Iskandar (2008) adalah teknik analisis yang prosesnya dilakukan dengan tiga langkah, yaitu (1) reduksi data; (2) penyajian data; dan (3) penarikan kesimpulan atau verifikasi. 


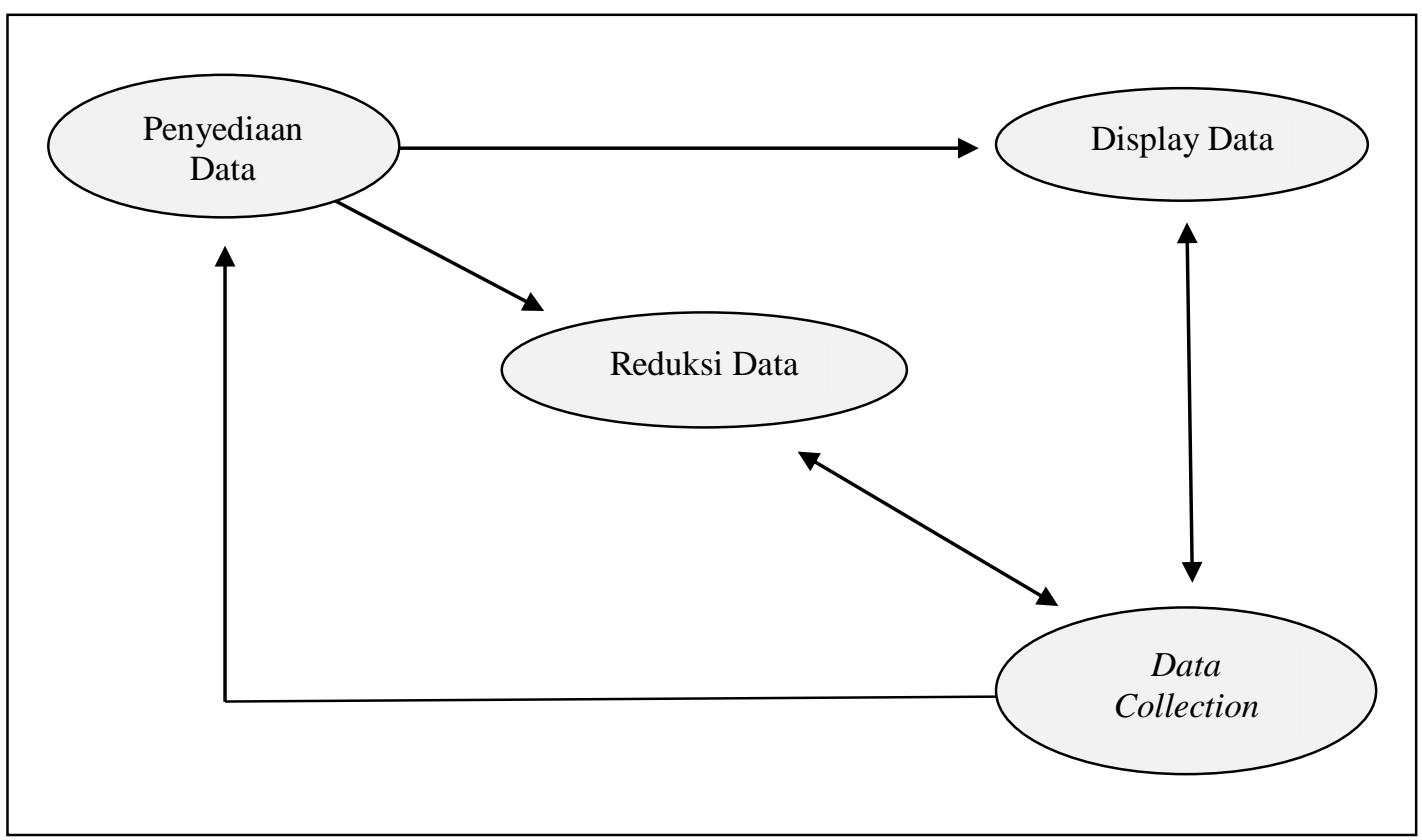

Gambar 1. Model Teknik Pengumpulan Data dan Analisis Data

(Iskandar, 2008)

Indikator keberhasilan penelitian ini adalah sebagai berikut:

1. Meningkatnya kemampuan siswa kelas XI IPS 4 SMA Negeri 1 Kawali dalam memahami kondisi wilayah dan posisi strategis Indonesia sebagai poros maritim dunia. Indikator penelitian ini bersumber dari silabus mata pelajaran geografi kelas XI IPS 4 SMA Negeri 1 Kawali tahun pelajaran 2019/2020 dengan Kriteria Ketuntasan Minimal (KKM) yaitu 75. Dengan kata lain, penelitian ini dapat dikatakan berhasil jika semua siswa kelas XI IPS 4 SMA Negeri 1 Kawali mendapat nilai di atas batas KKM (Ketuntasan Belajar 100\%).

2. Meningkatnya kualitas kinerja peneliti sehingga hasil observasi mendeskripkan kinerja peneliti minimal dalam kategori baik.

3. Meningkatnya perilaku siswa menjadi lebih positif terhadap pembelajaran sehingga hasil observasi mendeskripsikan perilaku siswa minimal dalam kategori baik.

\section{HASIL DAN PEMBAHASAN}

Hasil penelitian disajikan pada Tabel 1.

Tabel 1. Hasil Analisis terhadap Kinerja Guru

\begin{tabular}{llll}
\hline \multicolumn{1}{c}{ Kriteria } & \multicolumn{1}{c}{ Pra Siklus } & \multicolumn{1}{c}{ Siklus 1 } & \multicolumn{1}{c}{ Siklus 2 } \\
\hline Jumlah skor & 8 & 14 & 18 \\
Rata-rata skor & 1,33 & 2,33 & 3,00 \\
Kategori & Kurang & Cukup & Baik \\
\hline
\end{tabular}

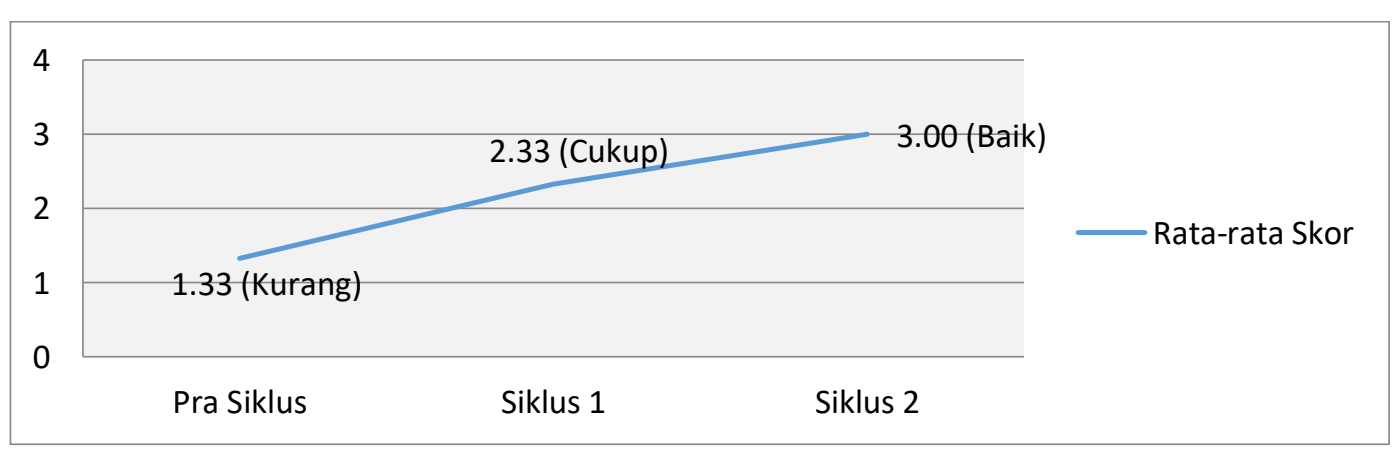

Gambar 2. Histogram Hasil Analisis terhadap Kinerja Guru 
Dari Tabel 1 dapat diketahui bahwa ada peningkatan pada kinerja peneliti. Pada tindakan pra siklus rata-rata skor kinerja peneliti adalah 1,33 (kategori kurang). Di akhir siklus 2, rata-rata skor kinerja peneliti meningkat menjadi 3,00 (kategori baik). Ini berarti bahwa indikator keberhasilan untuk kinerja peneliti telah tercapai.

Tabel 2. Hasil Analisis terhadap Perilaku Siswa

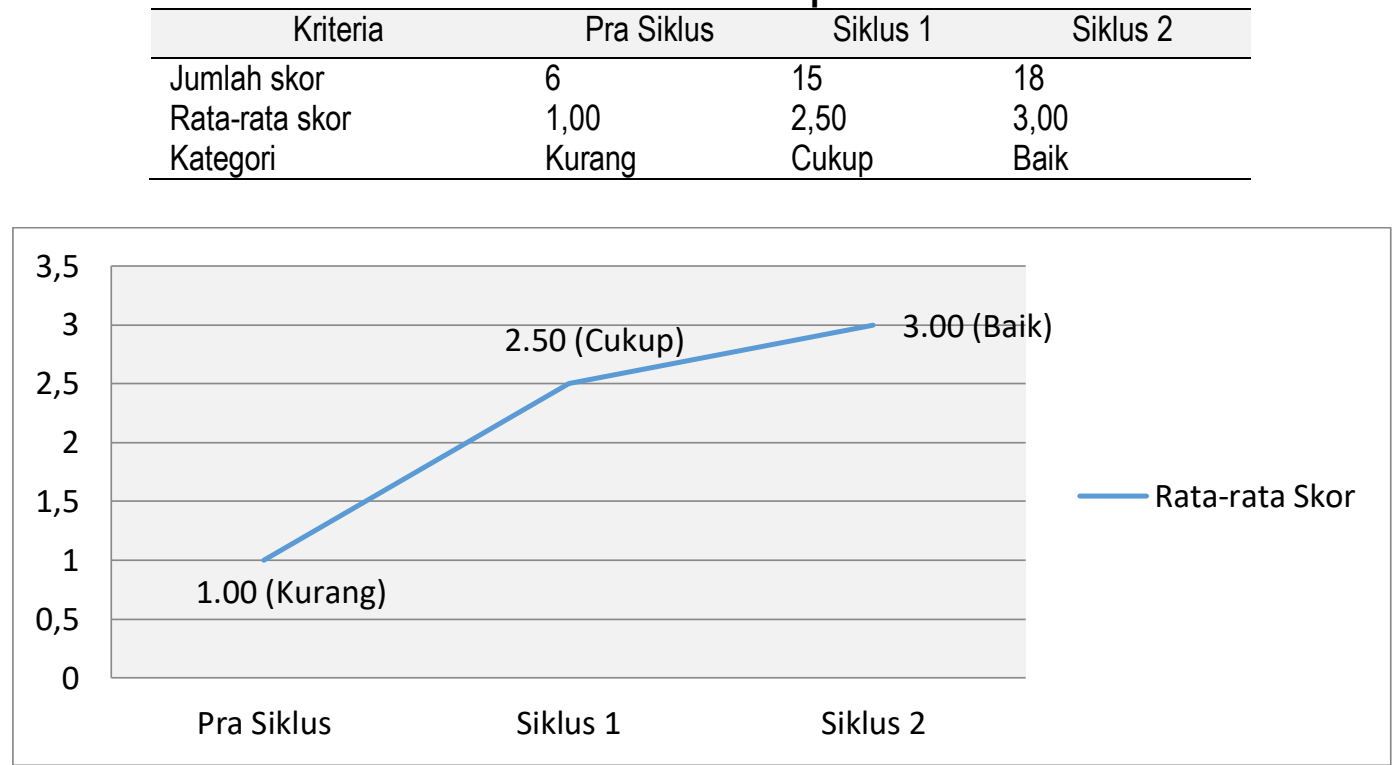

Gambar 3. Histogram Hasil Analisis terhadap Perilaku Siswa

Dari Tabel 2 dapat diketahui bahwa ada peningkatan pada perilaku siswa. Pada tindakan pra siklus rata-rata skor perilaku siswa adalah 1,00 (kategori kurang). Di akhir siklus 2, rata-rata skor perilaku siswa meningkat menjadi 3,00 (kategori baik). Ini berarti bahwa indikator keberhasilan untuk perilaku siswa telah tercapai.

Tabel 3. Hasil Analisis terhadap Kemampuan Siswa

\begin{tabular}{cccc}
\hline Kriteria & Pra Siklus & Siklus 1 & Siklus 2 \\
\hline Penguasaan Materi & $67.7 \%$ & $77.7 \%$ & $82.7 \%$ \\
Ketuntasan Belajar & $21.2 \%$ & $75.8 \%$ & $100 \%$ \\
\hline
\end{tabular}

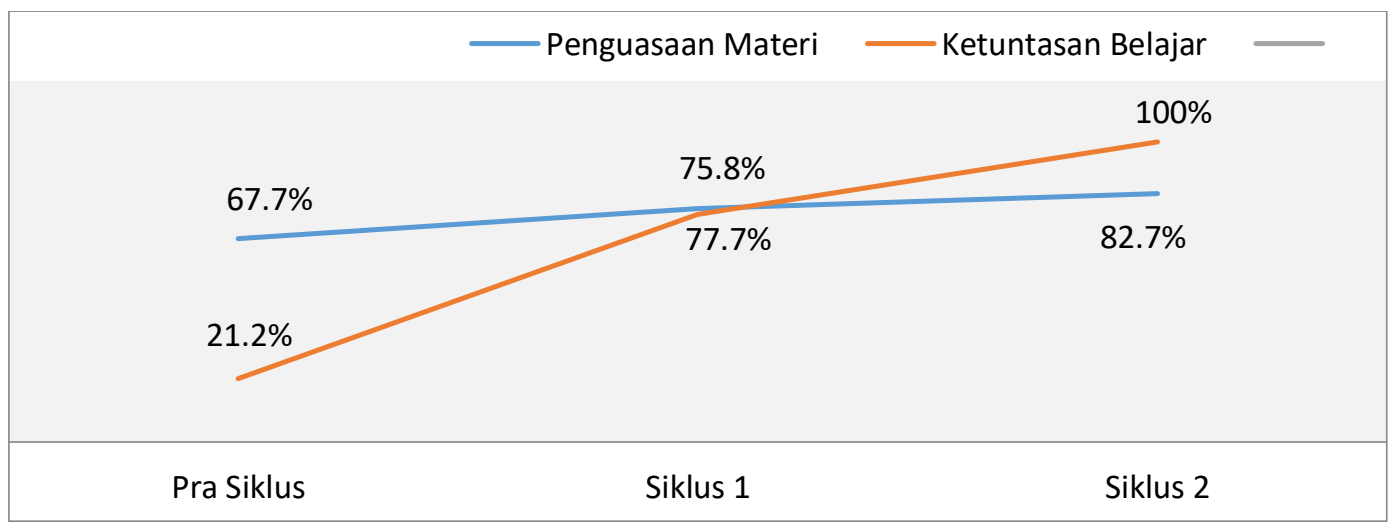

Gambar 4. Histogram Hasil Analisis terhadap Kemampuan Siswa

Dari data yang dikumpulkan dari tindakan pra siklus, siklus 1, dan siklus 2, peneliti melihat adanya peningkatan dalam persentase penguasaan materi (nilai rata-rata). Pada tindakan pra siklus penguasaan materi adalah $67,7 \%$. Di akhir siklus 2, jumlah ini meningkat menjadi $82,7 \%$. Ini berarti bahwa total peningkatan pada persentase penguasaan materi adalah sebesar $15 \%$. Sedangkan ketuntasan belajar, pada tindakan pra siklus persentasenya adalah $21,2 \%$. Pada siklus 2 , jumlahnya 
meningkat menjadi $100 \%$. Peneliti menghitung peningkatan persentase ketuntasan belajar adalah sebesar 78,8\%. Dari data ini dapat diketahui bahwa indikator keberhasilan untuk kemampuan siswa telah tercapai.

Dari data-data penelitian ini dapat disimpulkan bahwa hipotesis yang menyatakan "Metode STAD dapat meningkatkan kemampuan memahami kondisi wilayah dan posisi strategis Indonesia sebagai poros maritim dunia siswa kelas XI IPS 4 SMA Negeri 1 Kawali tahun pelajaran 2019/2020" dapat diterima karena semua indikator keberhasilan penelitian ini telah tercapai. Jadi, metode STAD dapat meningkatkan kemampuan memahami kondisi wilayah dan posisi strategis Indonesia sebagai poros maritim dunia siswa kelas XI IPS 4 SMA Negeri 1 Kawali tahun pelajaran 2019/2020.

STAD merupakan pembelajaran kooperatif yang paling sederhana. STAD digunakan untuk memberikan pemahaman konsep materi memahami kondisi wilayah dan posisi strategis Indonesia sebagai poros maritim dunia yang sulit kepada siswa kelas XI IPS 4 SMA Negeri 1 Kawali dimana materi tersebut telah dipersiapkan oleh peneliti melalui lembar kerja atau perangkat pembelajaran yang lain.

Metode STAD menekankan pada keterampilan bersama. Belajar dengan membentuk tim yang terdiri dari 4-5 anggota dan menitikberatkan pada pembagian tugas yang saling membantu dalam pembelajaran untuk menyelesaikan tugas yang diberikan oleh peneliti secara baik. Dengan demikian, setiap siswa kelas XI IPS 4 SMA Negeri 1 Kawali dapat menuntaskan materi pelajaran dengan baik. Sependapat dengan Nurholis (2016) bahwa menggunakan STAD berorientasi keterampilan proses dapat meningkatkan pemahaman dan aktivitas siswa, hal ini ditunjukkan adanya peningkatan ketuntasan klasikal, skor rata-rata postes dan aktivitas.

Metode STAD adalah sebuah metode yang efektif. Metode STAD membantu siswa kelas XI IPS 4 SMA Negeri 1 Kawali untuk berpartisipasi aktif dalam setiap tugas-tugas dalam kegiatan pembelajaran karena di dalamnya, siswa dapat melakukan suatu perbandingan terhadap objek bacaan, berbagi informasi dengan cara berdiskusi dengan peneliti dan temannya. Selain itu, metode STAD menciptakan suasana yang sehat dalam pembelajaran.

Di dalam metode STAD, siswa kelas XI IPS 4 SMA Negeri 1 Kawali dapat belajar dalam kelompok dengan anggota-anggota yang mungkin mempunyai kemampuan yang berbeda-beda sehingga mereka dapat mengerjakan tugas sebaik-baiknya dengan cara bekerjasama untuk mengoptimalkan kemampuan-kemampuan dari anggotanya tersebut. Dengan metode STAD, hasil belajar akademik siswa kelas XI IPS 4 SMA Negeri 1 Kawali meningkat dan siswa kelas XI IPS 4 SMA Negeri 1 Kawali dapat menerima berbagai keragaman dari temannya serta mengembangkan keterampilan sosial. Dalam proses pembelajaran STAD, siswa kelas XI IPS 4 SMA Negeri 1 Kawali didorong untuk bekerjasama pada suatu tugas bersama dan mereka harus mengoordinasikan usahanya untuk menyelesaikan tugas yang diberikan peneliti.

Dalam konteks penelitian ini, metode STAD terbukti dapat meningkatkan kemampuan siswa kelas XI IPS 4 SMA Negeri 1 Kawali dalam kegiatan-kegiatan akademik (Slavin, 1987), menciptakan sebuah motivasi yang besar terhadap pembelajaran, meningkatkan efektivitas waktu pembelajaran dalam menyelesaikan tugas (Cohen \& Benton, 1988), meningkatkan rasa percaya diri (Johnson \& Johnson, 1989), dan mengarahkan siswa kelas XI IPS 4 SMA Negeri 1 Kawali kepada kebiasaankebiasaan positif di kehidupan sosial, yakni bekerjasama (Lloyd, 1988). Untuk para siswa kelas XI IPS 4 SMA Negeri 1 Kawali, STAD juga menciptakan sebuah penguasaan materi dengan menghadirkan materi-materi yang sesuai dan relatif gampang serta mudah dimengerti oleh siswa. Selain itu, metode ini menciptakan sebuah suasana pembelajaran yang mendukung, nyaman dan lebih memotivasi siswa untuk belajar (Kagan, 1995). 


\section{KESIMPULAN}

Hasil penelitian memperlihatkan bahwa metode STAD terbukti dapat meningkatkan kemampuan siswa kelas XI IPS 4 SMA Negeri 1 Kawali dalam kegiatan-kegiatan akademik, menciptakan sebuah motivasi yang besar terhadap pembelajaran, meningkatkan efektivitas waktu pembelajaran dalam menyelesaikan tugas, meningkatkan rasa percaya diri, dan mengarahkan siswa kelas XI IPS 4 SMA Negeri 1 Kawali kepada kebiasaan-kebiasaan positif di kehidupan sosial, yakni bekerjasama. Untuk para siswa kelas XI IPS 4 SMA Negeri 1 Kawali, STAD juga menciptakan sebuah penguasaan materi dengan menghadirkan materi-materi yang sesuai dan relatif gampang serta mudah dimengerti oleh siswa. Selain itu, metode ini menciptakan sebuah suasana pembelajaran yang mendukung, nyaman dan lebih memotivasi siswa untuk belajar.

Kesimpulannya, metode STAD dapat meningkatkan kemampuan memahami kondisi wilayah dan posisi strategis Indonesia sebagai poros maritim dunia siswa kelas XI IPS 4 SMA Negeri 1 Kawali tahun pelajaran 2019/2020. Ini terbukti dengan adanya peningkatan pada persentase penguasaan materi sebesar $15 \%$ dan peningkatan persentase ketuntasan belajar sebesar $78,8 \%$.

\section{REKOMENDASI}

Laporan penelitian ini dapat digunakan peneliti-peneliti lain dan guru-guru untuk mengajarkan materi geografi sebagai bahan perbandingan dalam rangka menyusun pendekatan, metode, strategi, atau teknik pembelajaran yang efektif. Dalam situasi dan kondisi tertentu, metode STAD dapat sangat efektif karena model ini terbukti dapat mengatasi kendala-kendala yang dialami siswa kelas XI IPS 4 SMA Negeri 1 Kawali dalam pembelajaran geografi. Pada proses pembelajaran sebaiknya siswa lebih aktif dalam mengikuti pembelajaran dan tetap memperhatikan perkembangan teknologi dan informasi yang ada sehingga ilmu pengetahuan tentang kehidupan sosial dapat bertambah. Selanjutnya bagi guru geografi, diharapkan dapat melakukan penelitian-penelitian yang kreatif dan inovatif tentang mengajar dengan menggunakan media dan metode yang berbeda-beda sehingga ilmu pengetahuan dalam mengajar di kelas bisa lebih beragam.

\section{UCAPAN TERIMAKASIH}

Ucapan terima kasih ditujukan untuk siswa kelas XI IPS 4 SMA Negeri 1 Kawali tahun pelajaran 2019/2020 beserta kepala sekolah yang telah mendukung penelitian ini. Selain itu juga kepada observer (teman sejawat) yaitu Bapak Drs. Totong Budiarto dan Ibu Yeni Sulastri, S.Pd. yang telah ikut melancarkan kegiatan penelitian ini.

\section{DAFTAR PUSTAKA}

Arikunto,S. (2008). Dasar-dasar Evaluasi Pendidikan. Jakarta: Bumi Aksara.

Cohen, E.G., \& Benton, J. (1988). Making Groupwork Work. American Educator.v.12, 10- 17, 45-46.

Iskandar. (2008). Metodologi Penelitian Pendidikan dan Sosial (Kuantitatif dan Kualitatif). Jakarta: GP Press.

Johnson, D. W., \& Johnson, R. (1989). Cooperation and competition: Theory and research. Edina, $\mathrm{MN}$ : interaction Book Company.

Kagan, S. (1995). We Can Talk: Cooperative Learning in the Elementary ESL Classroom. ERIC Digest Reproduction No. ED 382035. 
Lloyd, J.W. (1988). Redefining the Applied Research Agenda: Cooperative Learning, Pre-Referral, Teacher Consultation, and Peer-Mediated Interventions. Journal of Learning Disabilities, 21, 43-52.

Nurholis, E. (2016). Penerapan Model Pembelajaran Kooperatif Tipe STAD dalam Pembelajaran Sejarah untuk Meningkatkan Kreativitas dan Hasil Belajar (Studi PTK pada Siswa Kelas XI di SMK Yasira Ciamis). Jurnal Artefak, 4 (2),111-120.

Slavin, R.E. (1987). Cooperative Learning and the Cooperative School. Educational Leadership, 45, 7-13. 